\section{Osmotic Priming or Chilling Stratification Improves Seed Germination of Purple Coneflower}

\author{
N. Wartidiningsih, R.L. Geneve, and S.T. Kester \\ Department of Horticulture and Landscape Architecture, University of \\ Kentucky, Lexington, KY 40546
}

Additional index words. osmoconditioning, PEG

\begin{abstract}
High germination seed lots of purple coneflower [Echinacea purpurea (L.) Moench] were evaluated for laboratory germination following osmotic priming or chilling stratification. Compared to nontreated seeds, osmotic priming at $25 \mathrm{C}$ in salts $\left(\mathrm{KNO}_{3}+\right.$ $\mathrm{K}_{3} \mathrm{PO}_{4} ; 1: 1$, w/w) or polyethylene glycol 4000 (PEG) increased early (3-day) germination percentage at $27 \mathrm{C}$ of all seed lots, and improved total (10-day) germination percentage of low-germination seed lots. Total germination percentage was unaffected or increased by priming for 4 days compared to 8 days, and by priming at $-1.0 \mathrm{MPa}$ compared to $-0.5 \mathrm{MPa}$ (except for one low-germination seed lot). Chilling stratification in water at 5 or 10C increased early and total germination of all seed lots, except for that same lot, compared to nontreated seeds. Total germination percentage was unaffected or increased by stratification at $10 \mathrm{C}$ rather than at $5 \mathrm{C}$. Neither extending stratification $\geq \mathbf{2 0}$ days nor lowering osmotic potential with PEG during stratification improved total germination percentage.
\end{abstract}

Purple coneflower is a popular herbaceous perennial native to central North America that is used principally as a component of directseeded "wildflower mixes" for highway plantings and for perennial plantings in home landscapes. However, field and greenhouse germination of purple coneflower has been poor. For Smith-Jochum and Albrecht (1987), field emergence was $<10 \%$ for direct-seeded purple coneflower. Similarly, Samfield et al. (1991) obtained only 39\% germination of purple coneflower seed under greenhouse conditions after 28 days. In laboratory studies, seed germination of purple coneflower has varied considerably between seed lots (Wartidiningsih and Geneve, 1994). This variation in germination was not related to several attributes of seed quality, including seed weight and maturity. The poor germination of these seed lots may be the result of environmental conditions during seed development or subsequent seed storage, low seed vigor, or seed dormancy.

Osmotic priming has improved germination performance in many agronomic and horticultural crops (Bradford, 1986). Osmotic priming is a technique of imbibing seeds in an osmotic solution under controlled conditions to maintain seeds in the desiccation-tolerant lag phase of germination (Bradford, 1986; Khan et al., 1980). Three fundamental aspects

Received for publication 4 Feb. 1994. Accepted for publication 12 July 1994. Paper no. 93-10-34 of the Kentucky Agricultural Experiment Station. We acknowledge the technical support of Pam Compton and grant support from the Association of Official Seed Analysts. The cost of publishing this paper was defrayed in part by the payment of page charges. Under postal regulations, this paper therefore must be hereby marked advertisement solely to indicate this fact. to seed priming (Frett and Pill, 1988; Khan et al., 1980) are osmotic potential, priming temperature, and priming duration. Osmotically primed seeds performed particularly well compared to nontreated seed when germination conditions were not optimal (Brocklehurst and Dearman, 1983; Heydecker and Coolbear, 1977).

Chilling stratification is another presowing seed treatment used to promote rapid and uniform germination in species with dormant seeds (Hartmann et al., 1990). Seeds are moistchilled ( 0 to $10 \mathrm{C}$ ) to cause physiological changes within the seed to relieve dormancy. Also, short periods of chilling stratification have improved germination in species that are considered not to have dormant seed. Impatiens (Impatiens wallerana Hook f.) seeds chilled for 14 days at $8 \mathrm{C}$ germinated faster than nontreated seeds (Simmonds, 1980).

Samfield et al. (1990, 1991) used seed priming to improve germination percentage and rate in a single seed lot of purple coneflower. Seeds primed for 6 or 9 days in water or phosphate buffer $(50 \mathrm{~mm})$ germinated faster and more uniformly than nontreated seeds in laboratory and greenhouse studies. Priming also improved germination following 2-month, open-air storage of purple coneflower seeds (Samfield et al., 1990).

The objective of these studies was to investigate the effect of osmotic priming and chilling stratification on germination of several seed lots of purple coneflower exhibiting a range of germinability.

\section{Material and Methods}

Germination tests were conducted using six seed lots of purple coneflower purchased from four seed companies. These included two seed lots of common purple coneflower
(P1 and P2), two of 'Bright Star' (B1 and B2), one of 'White Swan' (WS), and one of 'Bravado' $(\mathrm{Br})$. All seed packages indicated the current year's date and minimum germination of $>90 \%$.

Germination following all treatments was evaluated using 25 seeds placed in $(100 \times 15$ $\mathrm{mm}$ ) petri dishes containing two pieces of Whatman \#1 filter paper and $4 \mathrm{ml}$ of autoclaved, deionized water. Petri dishes were sealed with parafilm and placed in a dark incubator at 27C. Each treatment (petri dish) was replicated four times. Seeds were considered germinated when the radicle emerged. Germination percentage was determined after 3 (early germination) and 10 days (total germination). In general, germination was complete by 10 days.

Seeds were primed at 15 or $25 \mathrm{C}$ in salt or polyethylene glycol 4000 (PEG). Seeds (100 to 500) were suspended in cheesecloth bags in $500 \mathrm{ml}$ of aerated priming solution in 1-liter Erlenmeyer flasks. The priming solutions were prepared from equal weight percentages of $\mathrm{KNO}_{3}$ and $\mathrm{K}_{3} \mathrm{PO}_{4}(1.4 \%$ or $2.7 \%$ for -0.5 or $-1.0 \mathrm{MPa}$, respectively). The initial -0.5 or $-1.0 \mathrm{MPa}$ osmotic potential of the priming solution at $25 \mathrm{C}$ was verified by thermocouple psychrometry (model SC-10; Decagon Devices, Pullman, Wash.). All seed lots were primed at $25 \mathrm{C}$ for 4 or 8 days, and four seed lots (P1, P2, B1, and B2) were primed at 15C for 5,10 , or 15 days. The primed seeds were rinsed with deionized water and dried for $24 \mathrm{~h}$ at $25 \mathrm{C}$ in forced air before germination.

The effect of stratification on germination was studied with seeds from all six seed lots. Seeds (100) placed on two pieces of Whatman \#1 filter paper wetted with $10 \mathrm{ml}$ autoclaved deionized water in a $100 \times 15$-mm petri dish were held at 5 or $10 \mathrm{C}$ for $0,10,20$, or 30 days. The seeds were dried in forced air for $24 \mathrm{~h}$ at $25 \mathrm{C}$ before germination.

Each experiment was a completely randomized design using a factorial treatment arrangement. Germination percentages were transformed $(\arcsin \cdot \sqrt{\%})$ for statistical evaluation. Treatments were evaluated using single degree of freedom contrasts. The results are presented chronologically for single seed lots of each accession. Seed was stored at 5C in a sealed container. Experiments were conducted over 3 years, and germination percentage and rate of all seed lots decreased as the seed lots aged.

\section{Results}

Osmotic priming with salt or PEG at 25C increased early (3-day) and total (10-day) germination percentages of the low-germination seed lots (P2, B2, WS, and Br), but increased only early germination percentage of the highgermination seed lots (P1 and B1) compared to nontreated seeds (Table 1). For salt-primed seeds, $-1.0 \mathrm{MPa}$ was superior to $-0.5 \mathrm{MPa}$ in all low-germination seed lots except for P2 (Table 1). For PEG-primed seeds, $-1.0 \mathrm{MPa}$ only increased final germination compared to $-0.5 \mathrm{MPa}$ in WS and $\mathrm{Br}$ seed lots. All priming treatments increased early germination per- 
Table 1. Effect of priming six seed lots of purple coneflower with salt $\left(\mathrm{KNO}_{3}+\mathrm{K}_{3} \mathrm{PO}\right.$ ) or polyethylene glycol 4000 (PEG) at -0.5 or $-1.0 \mathrm{MPa}$ at $25 \mathrm{C}$ for 4 or 8 days on germination percentage after 3 or 10 days at $27 \mathrm{C}$.

\begin{tabular}{|c|c|c|c|c|c|c|c|c|c|c|c|c|c|c|}
\hline \multicolumn{3}{|c|}{ Priming conditions } & \multicolumn{12}{|c|}{ Seed lots ${ }^{2}$} \\
\hline \multirow[b]{3}{*}{ Osmoticum } & \multirow{3}{*}{$\begin{array}{c}\text { Osmotic } \\
\text { potential } \\
(\mathrm{MPa})\end{array}$} & \multirow{3}{*}{$\begin{array}{c}\text { Duration } \\
\text { (days) }\end{array}$} & \multicolumn{2}{|c|}{ P1 } & \multicolumn{2}{|c|}{$\mathrm{P} 2$} & \multicolumn{2}{|c|}{ B1 } & \multicolumn{2}{|c|}{ B2 } & \multicolumn{2}{|c|}{ WS } & \multicolumn{2}{|c|}{$\mathrm{Br}$} \\
\hline & & & \multicolumn{11}{|c|}{ Germination (\%) after 3 or 10 days } & \\
\hline & & & 3 & 10 & 3 & 10 & 3 & 10 & 3 & 10 & 3 & 10 & 3 & 10 \\
\hline \multirow[t]{4}{*}{$\mathrm{KNO}_{3}+\mathrm{K}_{3} \mathrm{PO}_{4}$} & -0.5 & 4 & 96 & 97 & 75 & 83 & 74 & 82 & 47 & 53 & 38 & 64 & 64 & 68 \\
\hline & -0.5 & 8 & 91 & 96 & 75 & 82 & 77 & 83 & 39 & 48 & 39 & 54 & 54 & 56 \\
\hline & -1.0 & 4 & 95 & 96 & 70 & 73 & 74 & 82 & 60 & 54 & 35 & 81 & 81 & 78 \\
\hline & -1.0 & 8 & 89 & 94 & 58 & 63 & 75 & 82 & 44 & 54 & 46 & 70 & 70 & 78 \\
\hline \multirow[t]{4}{*}{ PEG 4000} & -0.5 & 4 & 89 & 97 & 84 & 90 & 77 & 85 & 45 & 54 & 40 & 48 & 61 & 64 \\
\hline & -0.5 & 8 & 92 & 96 & 78 & 86 & 71 & 82 & 47 & 54 & 35 & 44 & 54 & 68 \\
\hline & -1.0 & 4 & 96 & 96 & 63 & 78 & 79 & 83 & 47 & 54 & 67 & 72 & 67 & 83 \\
\hline & -1.0 & 8 & 88 & 94 & 78 & 88 & 72 & 78 & 37 & 40 & 60 & 62 & 53 & 60 \\
\hline Nontreated seeds & & & 73 & 91 & 26 & 62 & 51 & 78 & 6 & 18 & 2 & 13 & 13 & 42 \\
\hline \multicolumn{15}{|l|}{ Contrasts } \\
\hline \multicolumn{11}{|l|}{$\begin{array}{l}\text { Nontreated vs. } \\
\text { salts }\end{array}$} & $* *$ & ** & & $* *$ \\
\hline \multicolumn{15}{|l|}{ Salts, $-0.5 \mathrm{MPa}$} \\
\hline vs. $-1.0 \mathrm{MPa}$ & & & NS & NS & $*$ & $* *$ & NS & NS & $*$ & NS & $* *$ & $* *$ & ** & ** \\
\hline \multicolumn{15}{|l|}{ Salts, 4 days vs. } \\
\hline 8 days & & & $*$ & NS & NS & $*$ & NS & NS & ** & NS & $* *$ & $* *$ & $*$ & $* *$ \\
\hline \multicolumn{15}{|l|}{ Nontreated vs. } \\
\hline PEG 4000 & & & $* *$ & NS & $* *$ & $* *$ & $* *$ & NS & $* *$ & $* *$ & $* *$ & $* *$ & $* *$ & $* *$ \\
\hline \multicolumn{3}{|c|}{ PEG, -0.5 MPa vs. } & & & & & & & & & & & & \\
\hline$-1.0 \mathrm{MPa}$ & & & NS & NS & * & NS & NS & NS & NS & NS & $* *$ & ** & NS & * \\
\hline \multicolumn{15}{|l|}{ PEG, 4 days vs. } \\
\hline 8 days & & & NS & NS & NS & $*$ & NS & NS & NS & NS & NS & $*$ & NS & * \\
\hline
\end{tabular}

${ }^{P} \mathrm{P} 1, \mathrm{P} 2$ = common purple coneflower; B1, B2 = 'Bravado'; WS = 'White Swan'; Br = 'Brightstar'. P1 and B1 = high-germination seed lots. P2, B2, WS, and Br = low-germination seed lots.

Ns, **** Nonsignificant or significant at $P \leq 0.05$ or 0.01 , respectively.

centage of all seed lots and total germination of all seed lots except $\mathrm{P} 1$ and B1 compared to nontreated seed (Table 1). Germination percentage was not increased by extending duration of priming in PEG or salts from 4 to 8 days (Table 1). Germination percentages were similar with salt or PEG priming, with 4 days at $-1.0 \mathrm{MPa}$ generally giving the highest germination percentage.

Compared to those nontreated, seeds of lots $\mathrm{P} 1, \mathrm{P} 2, \mathrm{~B} 1$, and $\mathrm{B} 2$ primed in PEG at $15 \mathrm{C}$ had higher early and total germination percentages (Table 2$)$. Osmotic potential $(-0.5$ or $-1.0 \mathrm{MPa}$ ) had no effect on germination percentage, but 10-day priming generally resulted in higher early and total germination percentages than priming for 5 or 15 days (Table 2).

Chilling stratification increased early and total germination percentages for all seed lots except WS, which germinated poorly $(<25 \%)$ (Table 3). Stratification for 10 days at $10 \mathrm{C}$ generally led to higher total germination than other stratification treatments (Table 3 ). Stratification at $10 \mathrm{C}$ compared to $5 \mathrm{C}$ either increased or had no effect on early or total germination percentage, depending on seed lot. Total germination percentage of all seed lots, except P2, was not increased by exceeding 10 days of stratification. Reducing the osmotic potential of the stratification liquid to -0.5 or $-1.0 \mathrm{MPa}$ with PEG failed to enhance the stratification effect (results not presented).

\section{Discussion}

Osmotic seed priming has improved germination in many plant species (Bradford, 1986), with increased germination rate generally being the greatest benefit (Heydecker and Coolbear, 1977). Osmotic seed priming increased the germination rate of all seed lots of purple coneflower in our experiments as indicated by higher percent germination after 3 days (Tables 1 and 2). This improvement in germination occurred regardless of the osmoticum, osmotic potential, priming temperature, or priming duration. No single priming treatment was optimum for all seed lots. To achieve similar improvement in germination percentages of seed lots, osmotic potential and priming duration solution had to be increased when priming was at 15 rather than at $25 \mathrm{C}$. Akalehiywot and Bewley (1977) observed that, at any given osmotic potential, longer priming at a lower temperature was required to obtain maximum stimulation of germination percentage of cereal grains after priming.

Samfield et al. (1991) obtained higher germination percentage and rate for a single seed lot of purple coneflower primed in distilled water or $50 \mathrm{~mm}$ potassium phosphate buffer for 6 or 9 days. In our study, total germination percentage was improved by seed priming only in low-germination seed lots (Tables 1 and 2). This seed "invigoration" (Heydecker et al., 1975) by priming was demonstrated in slow-germinating seed lots of several vegetables (Brocklehurst and Dearman, 1983).

The differences in germination improvement following osmotic priming may be attributed to differences in seed lot quality. In a previous study, we determined that initial seed quality of an open-pollinated seed lot of purple coneflower could not be attributed to seed weight, stage of seed maturity at harvest, or inflorescence position (Wartidiningsih and Geneve, 1994). Seed deterioration during storage could account for some of the differences in seed lot quality in this study. Deterioration was evident in high-germination (eg., P1, 79\% to $97 \%$ ) and low-germination (eg., P2, 29\% to $62 \%$ ) seed lots. Samfield et al. (1990) noted
$30 \%$ reduction in germination of purple coneflower seed stored 2 months in open containers compared to vacuum-sealed stored seed. This reduction in germination for open-stored seeds was restored almost totally by priming seeds for 6 days in 50 mm potassium phosphate buffer. Priming improved germination of deteriorating seeds in several species (Alvarado and Bradford, 1988; Dearman et al., 1986; Georghiou et al., 1987). Although seed aging may have contributed to the differences in seed quality observed between seed lots of purple coneflower, conditions during seed development also might affect seed quality. Alternatively, seed dormancy could explain the differences in initial seed germination between seed lots.

Chilling stratification to relieve seed dormancy improved seed germination in purple coneflower (Bratcher et al., 1993; Phillips, 1985; Pinnel et al., 1985). Smith-Jochum and Albrecht (1987) observed no consistent germination improvement of high-vigor purple coneflower seeds stratified at $0 \mathrm{C}$ for 1 month. In contrast, Hemmerly (1976) improved germination in purple coneflower from $20 \%$ to $92 \%$ by chilling stratification at $5 \mathrm{C}$ for 10 weeks. The contrasting results of these studies may be attributed to differences in seed lot quality or stratification temperature. In our study, stratification at 5 or $10 \mathrm{C}$ increased germination percentage (Table 3 ). Including PEG at -0.5 or $-1.0 \mathrm{MPa}$ compared to water alone during chilling at $10 \mathrm{C}$ did not affect germination. Not all seeds within a seed lot of purple coneflower could be considered dormant since seed lots P1 and B1 germinated between $78 \%$ and $91 \%$ without treatment (Table 1). Although seed dormancy could not be eliminated as a cause for the reduced germination percentages observed in our seed lot, 
Table 2. Effect of priming four seed lots of purple coneflower with PEG at -0.5 or $-1.0 \mathrm{MPa}$ at $15 \mathrm{C}$ for 5,10 , or 15 days on germination percentage after 3 or 10 days at $27 \mathrm{C}$

\begin{tabular}{|c|c|c|c|c|c|c|c|c|c|}
\hline \multicolumn{2}{|c|}{ Priming conditions } & \multicolumn{8}{|c|}{ Seed lots ${ }^{2}$} \\
\hline \multirow{3}{*}{$\begin{array}{l}\text { Osmotic } \\
\text { potential } \\
(\mathrm{MPa})\end{array}$} & \multirow{3}{*}{$\begin{array}{c}\text { Duration } \\
\text { (days) }\end{array}$} & & & & & & & & \\
\hline & & \multicolumn{8}{|c|}{ Germination (\%) after 3 or 10 days } \\
\hline & & 3 & 10 & 3 & 10 & 3 & 10 & 3 & 10 \\
\hline-0.5 & 5 & 90 & 92 & 80 & 74 & 74 & 85 & 36 & $\overline{66}$ \\
\hline-0.5 & 10 & 92 & 97 & 86 & 89 & 89 & 91 & 72 & 81 \\
\hline-0.5 & 15 & 75 & 88 & 63 & 81 & 81 & 84 & 71 & 79 \\
\hline-1.0 & 5 & 89 & 90 & 65 & 84 & 84 & 92 & 43 & 65 \\
\hline-1.0 & 10 & 93 & 97 & 86 & 89 & 89 & 91 & 59 & 76 \\
\hline-1.0 & 15 & 90 & 92 & 69 & 78 & 78 & 82 & 67 & 74 \\
\hline Nontreate & & 57 & 86 & 12 & 54 & 55 & 73 & 22 & 43 \\
\hline \multicolumn{10}{|c|}{ Contrasts } \\
\hline \multicolumn{10}{|c|}{ Nontreated seed vs. } \\
\hline$-0.5 \mathrm{MI}$ & & NS & NS & NS & NS & NS & NS & NS & NS \\
\hline 5 days $v$ & & NS & NS & NS & NS & $*$ & NS & $* *$ & $* *$ \\
\hline 5 days $、$ & & NS & NS & ** & $* *$ & NS & $*$ & $* *$ & $*$ \\
\hline 10 days & & $*$ & NS & $* *$ & $* *$ & NS & $* *$ & NS & NS \\
\hline
\end{tabular}

${ }^{2} \mathrm{P} 1, \mathrm{P} 2$ = common purple coneflower; B1, B2 = 'Bravado'.

Ns, ${ }^{, * * *}$ Nonsignificant or significant at $P \leq 0.05$ or 0.01 , respectively.

Table 3. Effect of chilling stratification of six seed lots of purple coneflower at 5 or $10 \mathrm{C}$ for 10, 20, or 30 days on germination percentage after 3 or 10 days at $27 \mathrm{C}$.

\begin{tabular}{|c|c|c|c|c|c|c|c|c|c|c|c|c|c|}
\hline & & \multicolumn{12}{|c|}{ Seed lots ${ }^{2}$} \\
\hline \multicolumn{2}{|c|}{ Stratification conditions } & \multicolumn{2}{|c|}{ P1 } & \multicolumn{2}{|c|}{$\mathrm{P} 2$} & \multicolumn{2}{|c|}{ B1 } & \multicolumn{2}{|c|}{ B2 } & \multicolumn{2}{|c|}{ WS } & \multicolumn{2}{|c|}{$\mathrm{Br}$} \\
\hline & Duration & \multicolumn{12}{|c|}{ Germination (\%) after 3 or 10 days } \\
\hline Temp $\left({ }^{\circ} \mathrm{C}\right)$ & (days) & 3 & 10 & 3 & 10 & 3 & 10 & 3 & 10 & 3 & 10 & 3 & 10 \\
\hline 5 & 10 & 73 & 82 & 24 & 28 & 65 & 71 & 8 & 17 & 11 & 23 & 6 & 28 \\
\hline 5 & 20 & 76 & 82 & 52 & 54 & 70 & 74 & 12 & 16 & 13 & 23 & 37 & 44 \\
\hline 5 & 30 & 86 & 95 & 35 & 44 & 83 & 93 & 20 & 22 & 10 & 16 & 52 & 74 \\
\hline 10 & 10 & 73 & 93 & 46 & 68 & 92 & 94 & 60 & 70 & 16 & 18 & 58 & 78 \\
\hline 10 & 20 & 90 & 92 & 67 & 78 & 81 & 81 & 17 & 29 & 8 & 9 & 57 & 68 \\
\hline 10 & 30 & 85 & 93 & 58 & 76 & 82 & 93 & 48 & 57 & 7 & 10 & 54 & 68 \\
\hline Nontreated seeds & & 54 & 79 & 8 & 29 & 17 & 53 & 3 & 34 & 8 & 22 & 3 & 28 \\
\hline \multicolumn{14}{|l|}{ Contrasts } \\
\hline Nontreated vs. treated seeds & & $* *$ & $*$ & $* *$ & $* *$ & $* *$ & $* *$ & $* *$ & $*$ & NS & NS & $* *$ & $* *$ \\
\hline $5 \mathrm{C}$ vs. $10 \mathrm{C}$ & & NS & NS & $* *$ & $* *$ & $* *$ & NS & $* *$ & $* *$ & NS & NS & $* *$ & $* *$ \\
\hline 10 days vs. 20 days & & $* *$ & NS & $* *$ & $* *$ & NS & NS & $* *$ & $* *$ & NS & NS & $* *$ & NS \\
\hline 10 days vs. 30 days & & $* *$ & NS & $* *$ & $* *$ & NS & $* *$ & NS & NS & NS & NS & $* *$ & $* *$ \\
\hline 20 days vs. 30 days & & NS & NS & $* *$ & $*$ & NS & $*$ & $* *$ & $* *$ & NS & NS & NS & $* *$ \\
\hline
\end{tabular}

${ }^{2} \mathrm{P} 1, \mathrm{P} 2$ = common purple coneflower; B1, B2 = 'Bravado'; WS = 'White Swan'; Br = 'Brightstar'.

${ }_{\mathrm{Ns},}, *{ }^{* *}$ Nonsignificant or significant at $P \leq 0.05$ or 0.01 , respectively.

germination percentage was increased by osmotic priming or chilling stratification. Chilling temperatures, however, were not required for improved germination. Seeds osmotically primed at $25 \mathrm{C}$ had higher germination percentages than nontreated seeds (Table 1). Chilling stratification increased germination in Impatiens wallerana Hook F., a species considered not to have dormant seed (Simmonds, 1980). Chilling stratification also could be considered as a treatment to improve germination of low-vigor purple coneflower seeds.

Regardless of the mechanism for improved germination, the results of this study indicated considerable variation in germination potential between seed lots of purple coneflower. Germination percentage of low-germination seed lots can be increased by priming or chilling stratification. However, laboratory germination may not always relate well to greenhouse or field germination. Conditions during germination also may affect the response to seed presowing treatments. Finnerty and Zajicek (1992) primed a single seed lot of purple coneflower and conducted emergence studies at two greenhouse locations. At one location, emergence percentage increased following seed priming, but at a second location, where the germination conditions were optimized, priming had no effect on seedling emergence.

When seed lot viability is high but germination is low, or the conditions for germination are less than optimal, a presowing seed treatment could be beneficial. Either osmotic priming using $\mathrm{PEG}$ at $-1.0 \mathrm{MPa}$ (4 days at $25 \mathrm{C}$ or 10 days at $15 \mathrm{C}$ ) or chilling stratification (10C for 20 days) improved germination in purple coneflower. Chilling stratification, however, required little expertise or specialized equipment. Stratified or primed seeds can be dried and sown by automated seeders.

\section{Literature Cited}

Akalehiywot, T. and J.D. Bewley. 1977. Promotion and synchronization of cereal grain germination by osmotic pretreatment with polyethylene glycol. J. Agr. Sci. 89:503-506.

Alvarado, A.D. and K.J. Bradford. 1988. Priming and storage of tomato (Lycopersicum lycopersicum) seeds. II. Influence of a second treatment after storage on germination and field emergence. Seed Sci. Technol. 16:613-623.

Bradford, K.J. 1986. Manipulation of seed water relations via osmotic priming to improve germination under stress conditions. HortScience 21:1105-1113.
Bratcher, C.B., J.M. Dole, and J.C. Cole. 1993 Stratification improves seed germination of five native wildflower species. HortScience 28:899901.

Brocklehurst, P.A. and J. Dearman. 1983. Interaction between seed priming treatment and nine seed lots of carrot, celery and onion. I. Laboratory germination. Ann. Appl. Biol. 102:577584 .

Dearman, J., P.A. Brocklehurst, and R.L.K. Drew. 1986. Effects of osmotic priming and ageing on onion seed germination. Ann. Appl. Biol. 108:639-648.

Finnerty, T. and J.M. Zajicek. 1992. Effects of seed priming on plug production of Coreopsis lanceolata and Echinacea purpurea. J. Environ. Hort. 10:129-132.

Frett, J.J. and W.G. Pill. 1988. Priming for the future. Greenhouse Grower 6:109-110.

Georghiou, K., C.A. Thanos, and H.C. Passam. 1987. Osmoconditioning as a means of counteracting the ageing of pepper seeds during high temperature storage. Ann. Bot. 60:279-285.

Hartmann, H.T., D.E. Kester, and F.T. Davies, Jr. 1990. Plant propagation principles and practices. 5th ed. Prentice Hall, Englewood Cliffs, N.J.

Hemmerly, T.E. 1976. Life cycle of a highly endemic cedar glade species: Echinacea tennesseensis (compositae). PhD Diss., Vanderbilt Univ., Nashville. 


\section{Crop Production}

Heydecker, W., J. Higgins, and Y.J. Turner. 1975. Invigoration of seeds? Seed Sci. Technol. 3:881-888.

Heydecker, W. and P. Coolbear. 1977. Seed treatments for improved performance-Survey and attempted prognosis. Seed Sci. Technol. 5:353425.

Khan, A.A., N.H. Peck, and C. Samimy. 1980. Seed osmoconditioning: Physiological and biological changes. Israel J. Bot. 29:133-144.

Phillips, H.R. 1985. Growing and propagating wild flowers. Univ. of North Carolina Press, Chapel Hill.
Pinnel, M.M., A.M. Armitage, and D. Seaborn. 1985. Germination needs of common perennial seed. Univ. of Georgia, College of Agr., Expt. Sta., Athens.

Samfield, D.M., J. Zajicek, and B.G. Cobb. 1990. Germination of Coreopsis lanceolata and Echinacea purpurea seeds following priming and storage. HortScience 25:1605-1606.

Samfield, D.M., J. Zajicek, and B.G. Cobb. 1991. Rate and uniformity of herbaceous perennial seed germination and emergence as affected by priming. J. Amer. Soc. Hort. Sci. 116:10-13.
Simmonds, J. 1980. Increasing seedling establishment of Impatiens wallerana in response to low temperature or polyethylene glycol seed treatments. Can. J. Plant Sci. 60:561-569.

Smith-Jochum, C.C. and M.L. Albrecht. 1987. Field establishment of three Echinacea species for commercial production. Acta Hort. 208:115119.

Wartidiningsih, N. and R.L. Geneve. 1994. Seed source and quality influence germination in purple coneflower [Echinacea purpurea (L.) Moench.]. HortScience 29:1443-1444. 